\title{
Role of Feeding in the Treatment of Dogs with Pancreatic Degenerative Atrophy
}

\author{
By Elias Westermarck, Maria Wiberg and Juha Junttila \\ Department of Medicine and Department of Animal Hygiene, \\ College of Veterinary Medicine, Helsinki, Finland.
}

\begin{abstract}
Westermarck, E., M. Wiberg and J. Junttila: Role of feeding in the treatment of dogs with pancreatic degenerative atrophy. Acta vet. scand. 1990, 31, 325-331. Fourteen dogs with pancreatic degenerative atrophy (PDA) were fed their original diets or a special diet for 2 periods of 4 weeks to compare the severety of clinical signs in relation to different types of diet. During the first period, the dogs were given ordinary food, and in the second period, the dogs were given only the special diet that consisted of a commercial moderate-fat, low-fiber, highly-digestible food. In addition, equal amounts of pancreatic enzymes were added into the food during both periods. The owners were given a questionnaire covering 9 typical signs of PDA. They were asked to assess the severity of signs daily for the 2 periods using a scale provided with the questionnaire.

The general well-being of the dogs was significantly $(\mathrm{p}<0.05)$ better during the period when the dogs were fed a special diet. Of the individual clinical signs associated with PDA the severity of flatulence, borborygmi, volume of faeces and frequency of defecation were significantly $(p<0.05)$ decreased on the special diet. There were no significant differences in appetite, drinking, colour and consistency of the faeces or in coprophagy between the 2 feeding periods.

The costs of the special diet were almost double compared to the ordinary diets.
\end{abstract}

dog; pancreatic degenerative atrophy; special diet; maldigestion; clinical signs; economy.

\section{Introduction}

In dogs with pancreatic degenerative atrophy (PDA), the exocrine part of the pancreas excretes hardly any digestive enzymes. As a result, most food is not digested and the dogs exhibit signs accordingly. Typically, the dogs eat large amounts of food but lose weight. Their feaces are usually grey or yellowish, voluminous and of a pulpy or loose consistency. The dogs defecate frequently and often eat their own faeces. Other signs of PDA are borborygmi, flatulence and polydipsia (Räihä \& Westermarck 1989).

The disease is irreversible and affected dogs need continuous treatment. It is essential to add pancreatic enzymes into their food.
Powder has been found to be the most efficacious form of supplementation (Strombeck 1979). Pancreatic enzymes can also be given by adding raw, chopped pancreas into the food (Westermarck 1987). Gastric acid secretion inhibitors and antacids have also been used in the treatment of PDA because most of the oral pancreatic enzyme supplementation is destroyed by gastric acids. Antibiotics have also been used, because dogs with PDA often have bacterial overgrowth in the small intestine (Batt \& McLean 1987, Williams et al. 1987).

There are few studies on the role of feeding in the treatment of dogs with PDA. Pidgeon (1982) concluded in his studies with pancreatic duct-ligated dogs that correct feeding is 
the most important single form of treatment. It gave better results than feeding with normal dog food and administration of pancreatic enzymes, a gastric acid secretion inhibitor and an antacid. However, Pidgeon later (1987) suggested that his studies might have been flawed because he used antacids that interfered with the enxyme supplementation. Pidgeon (1982) fed the dogs with a special commercial moderate-fat, low-fibre, highly-digestible food ${ }^{1}$ designed for dogs suffering from gastrointestinal diseases and recommended for dogs with PDA (Meyer 1985, Lewis et al. 1987). In children with cystic fibrosis, the symptoms of pancreatic insufficiency are controlled with effective pancreatic enzyme supplements and the children do not need any dietary restrictions (Beverly et al. 1987).

The objectives of the present study were to investigate alterations in the severity of clinical PDA signs when ordinary diets were

1 Prescription diet i/d (dry), Hill's, Topeka, Kansas.

Table 1. Data on dogs with PDA in the feeding trial, enzyme supplementation used, and costs and contents of the diets. Foods included in ordinary diets are given in their order of importance. GSD $=$ German Shepherd Dog.

\begin{tabular}{|c|c|c|c|c|c|c|}
\hline \multirow[b]{2}{*}{ Number } & \multirow[b]{2}{*}{ Breed } & \multirow{2}{*}{$\begin{array}{l}\text { Enzyme } \\
\text { supplement }\end{array}$} & \multicolumn{2}{|l|}{ Ordinary food period } & \multicolumn{2}{|c|}{ Special diet period } \\
\hline & & & Main contents & Price FIM & Amount kg & Price FIM \\
\hline 1. & GSD & Pancreas & Dry food & 141 & 11.7 & 468 \\
\hline 2. & GSD & Pancreas & Dry food, scalloped liver & 148 & 11.8 & 472 \\
\hline 3. & GSD & Pancreas & Canned food, rice & 180 & 14.4 & 576 \\
\hline 4. & GSD & Pancreas & Dry food, ground meat, bread & 214 & 8.9 & 356 \\
\hline 5. & GSD & Pancreas & Porridge, rice, dry food & 186 & 11.1 & 444 \\
\hline 6. & GSD & Pancreas & Dry food, porridge, ground meat & 178 & 10.1 & 404 \\
\hline 7. & Collie & Pancreas & Dry food & 84 & 3.9 & 156 \\
\hline 8. & GSD & Viokase & Dry food & 200 & 12.6 & 504 \\
\hline 9. & GSD & Viokase & Ground meat, rice, meat, egg & 314 & 10.1 & 404 \\
\hline 10. & Collie & Viokase & Dry food, porridge, cottage cheese & 232 & 5.8 & 232 \\
\hline 11. & Collie & Viokase & Dry food, coconut oil & 168 & 3.0 & 120 \\
\hline 12. & Collie & Viokase & Scalloped liver, dry food, fish & 350 & 9.0 & 360 \\
\hline 13. & Collie & Viokase & Dry food, ground meat, sausage & 220 & 7.2 & 286 \\
\hline 14. & GSD & Viokase & Dry food, sausage, macaroni & 330 & 13.5 & 540 \\
\hline
\end{tabular}


dogs received no other medication during the trial, but antibiotics had been used, particularly during the initial stage of their illness.

The trial was divided in two 4 weeks periods. During the first period, the dogs were given their ordinary food twice a day. Thereafter, they were gradually accustomed to the special diet during 1 week. During the second period, the dogs were given only the special food, twice a day.

The ordinary diet differed from dog to dog and usually consisted of both commercial dog food and home-made food (Table 1).

Table 2. Typical signs of PDA, assessed daily by the owners. Signs were scored in such a way that the higher the score, the more typical the symptom of PDA.

\begin{tabular}{rlrl}
\hline Appetite & Consistency of faeces \\
0 & $=$ very poor & 0 & $=$ hard \\
1 & $=$ poor & 1 & $=$ normal \\
2 & $=$ normal & 2 & $=$ loose, watery \\
3 & $=$ good & 3 & $=$ pulpy, mal- \\
4 & $=$ very good & & digested \\
5 & $=$ excessive & & \\
Drinking & Colour of faeces \\
0 & $=$ less than normal & 0 & $=$ darker than \\
1 & $=$ normal & & normal \\
2 & $=$ more than normal & 1 & $=$ normal \\
& & 2 & $=$ grey or \\
Defecation frequency/day & Coprophagia \\
0 & $=$ once & & yellowish \\
1 & $=$ twice & & $=$ no \\
2 & $=3$ times & 1 & $=$ yes \\
3 & $=\geq 4$ times & & \\
Volume of faeces & & Flatulence \\
0 & $=$ normal & 0 & $=$ no \\
1 & $=$ copious & 1 & $=$ some \\
2 & $=$ very copious & 2 & $=$ frequent \\
Borborygmi & & & \\
0 & $=$ no & & \\
1 & $=$ some & & \\
2 & $=$ frequent & & \\
\hline & & &
\end{tabular}

The owners were allowed to plan the feeding of their dogs themselves. The special diet consisted of a commercial dry food ${ }^{3}$ designed for dogs suffering from intestinal diseases.

The owners were given a questionnaire covering 9 typical signs of PDA. They were asked to assess the severity of signs daily for the 2 periods using a scale provided with the questionnaire (Table 2). The signs were scored in such a way that 0 represented the sign most atypical of PDA. The higher the number, the more typical of PDA the sign became. There were 2 to 5 alternatives for each sign.

The dogs were weighed weekly. The aim was to keep their body weights unchanged throughout the trial.

At the end of the trial, the owners calculated the monthly 'costs of ordinary feeding and the special diet.

\section{Statistical analysis}

Mean scores for each PDA sign were calculated for all dog and diet combinations. A new variable was established by totalling the daily scores for each dog. This was designated the PDA index. Daily PDA index scores were averaged over the 2 periods and all dogs. As a result, 10 continuous variables for every dog were obtained. The original 9 variables (Table 2) described the severity of individual PDA signs and the PDA index estimated general well-being during each period.

The significances of differences in average mean scores for each PDA sign during the 2 feeding periods were assessed using the Student's t-test, as were the differences in PDA indices between the feeding periods and the different forms of enzyme supplementation.

${ }^{3}$ Prescription diet i/d (dry), Hill's, Topeka, Kansas. 


\section{Results}

Comparison of the severity of typical PDA signs in these 14 dogs on ordinary diets and on the special diet showed that clinical signs (as reflected in the PDA index) were significantly reduced $(\mathrm{p}<0.05)$ on the special diet. Daily fluctuations in signs also decreased on the special diet (Fig. 1).

In 8 dogs, the severity of the clinical signs typical of PDA decreased significantly. In 4 dogs, the signs were alleviated only to some extent. In 2 dogs, the signs became slightly more severe on the special diet (Fig. 2).

Comparison of differences between scores for clinical PDA signs during the 2 feeding periods revealed that the occurrence of flatulence and borborygmi, volume of faeces and frequency of defecation decreased significantly $(p<0.05)$ on the special diet. There were no significant differences in appetite, drinking, colour and consistency of the faeces, and coprophagy between the 2 feeding periods (Fig. 3). Using correlation analysis, none of the signs were found to correlate positively with each other.

Half of the dogs received the enzyme supplement in the form of powder, and half received it in the form of raw pancreas mixed into their food. There were no significant differences in the severity of clinical signs between the 2 groups on their ordinary diets or on the special diet.

The difference between feeding costs with the ordinary diets and special diet was considerable. The average cost of the ordinary diets per dog was FIM 211 per period and FIM 380 for the special diet, respectively. Differences between the costs were particularly great regarding home-made food (Table 1). For $1 \mathrm{dog}$, the ordinary diet was more expensive. For another, the ordinary diet was as expensive as the special diet.

The price of the enzyme supplement added to the food was, on average, FIM 212 per period using the powder form and FIM 42 using raw pancreas. The cheapest form of

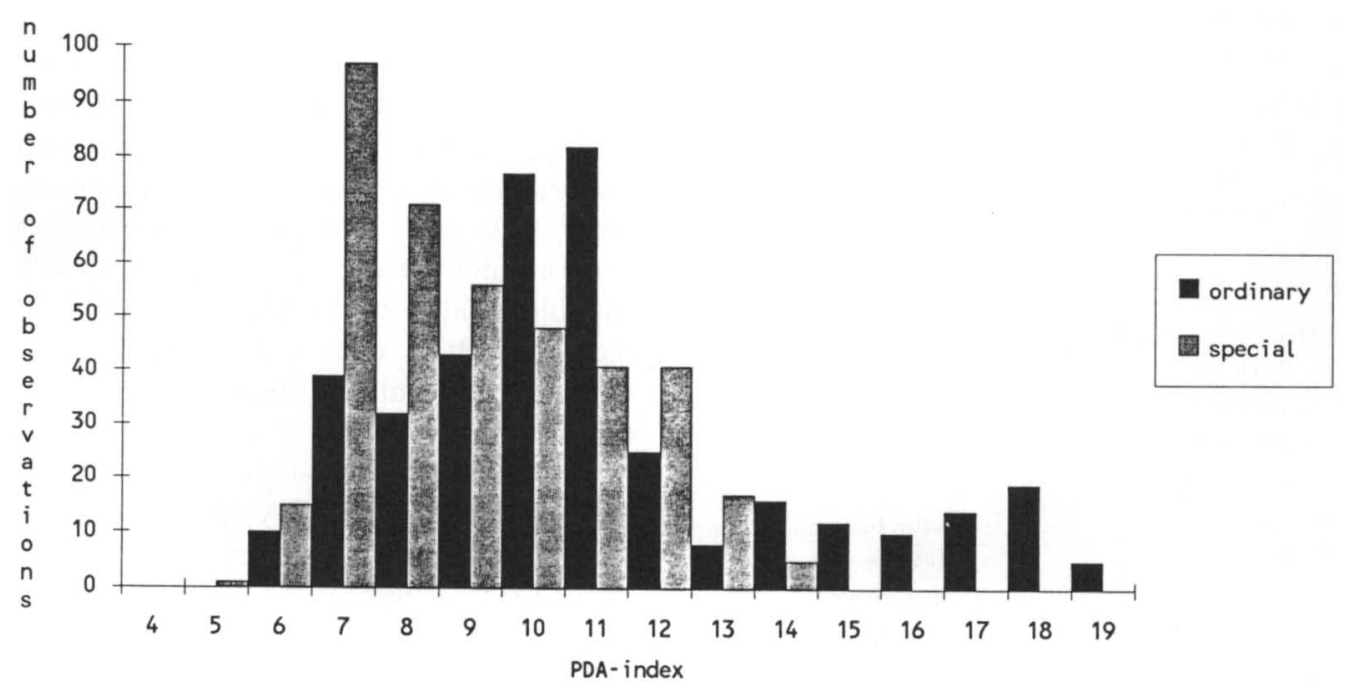

Figure 1. Distributions of daily PDA indices on ordinary diets and on the special diet. The PDA index is the sum of the scores for each sign. The PDA index increases as signs typical of PDA become more severe.

The figure shows that the signs were alleviated and their daily fluctuations reduced on the special diet. 


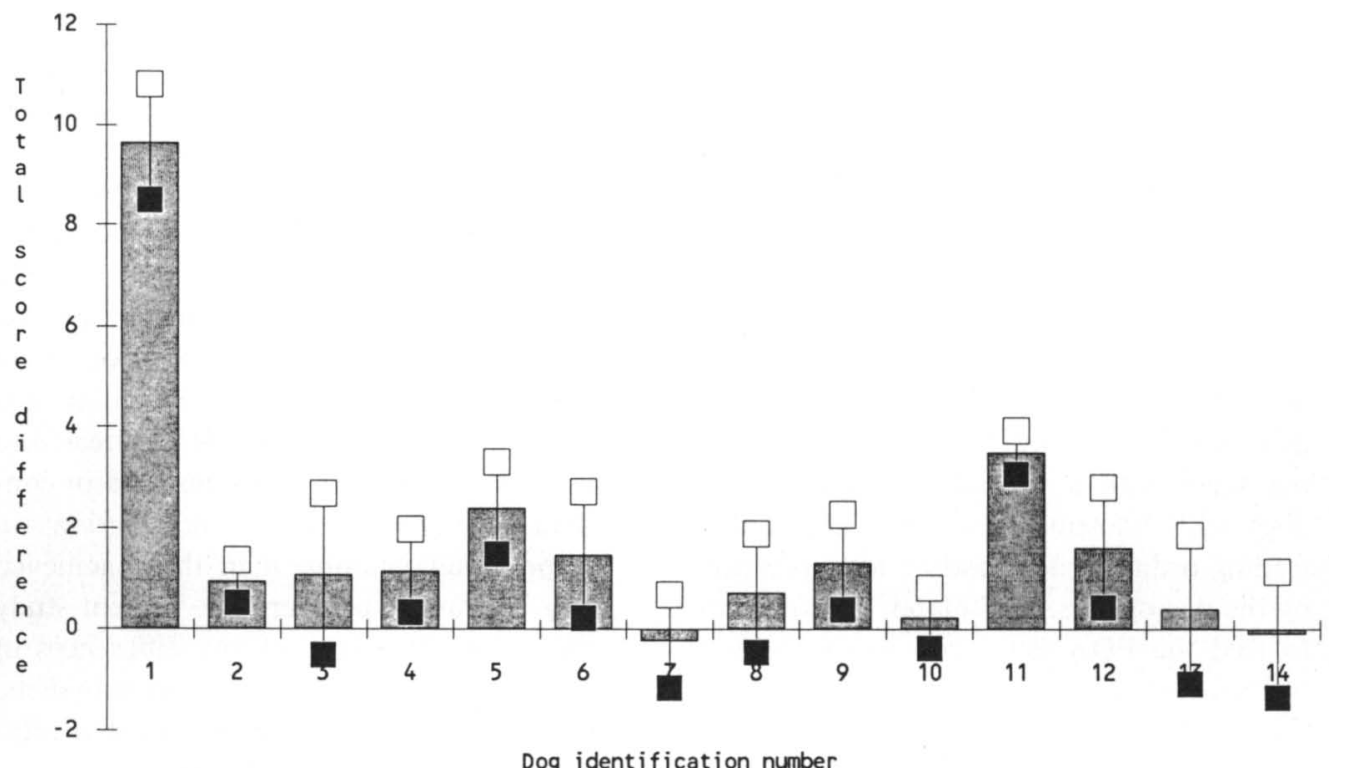

Figure 2. Comparison of sores reflecting the severity of clinical signs in 14 dogs with PDA on ordinary diets and on the special diet. The zero level represents the situation on ordinary diets. The higher the column, the more the score for PDA signs decreased on the special diet. The columns show $95 \%$ confidence intervals.

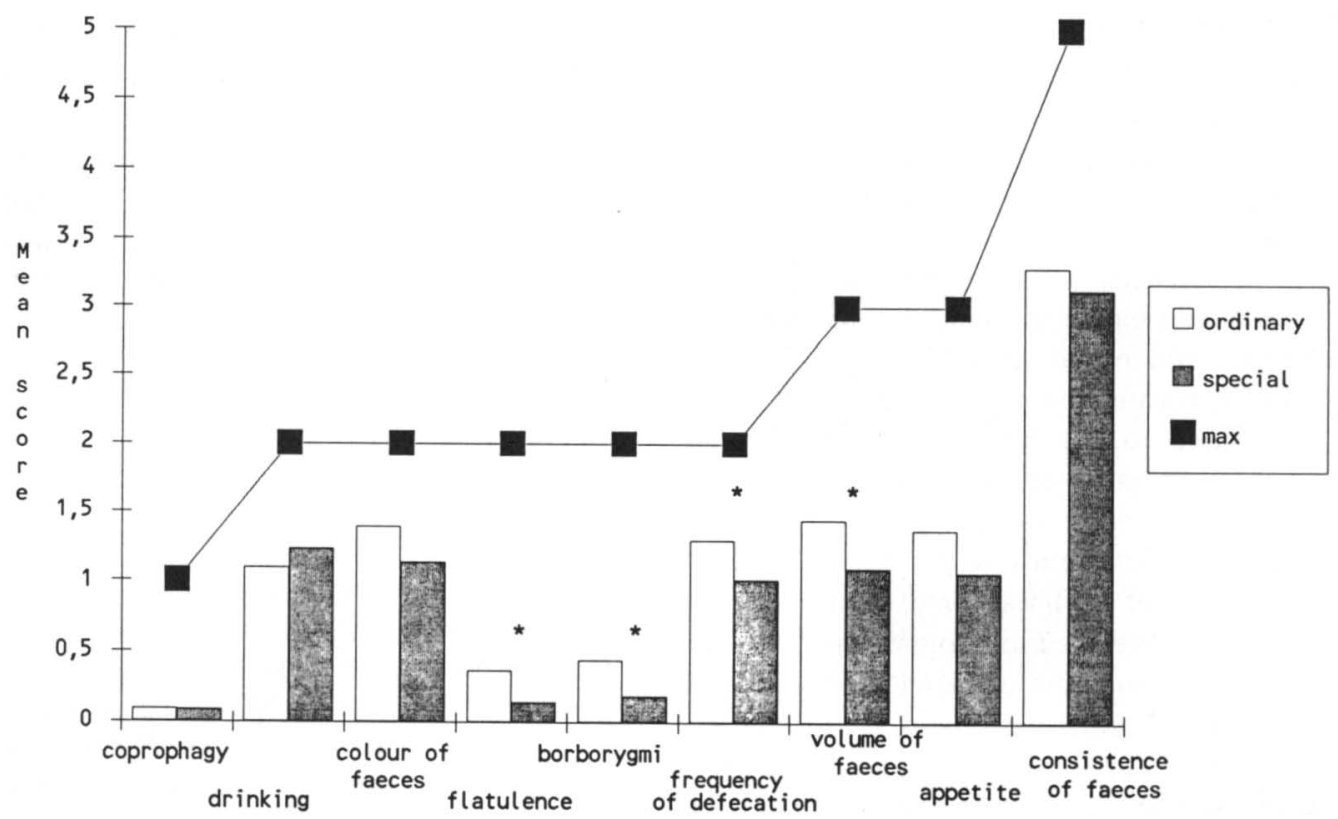

Figure 3. The severity of PDA signs on ordinary diets and on the special diet. The columns increase in height as the score for the sign becomes more typical of PDA. The "max" line is the maximum score for each sign. An asterisk $\left(^{*}\right)$ indicates a significant difference $(p<0.05)$ between diets. 
treatment, ordinary food plus raw pancreas, costs, on average, FIM 203 per period. The most expensive treatment, the special diet plus enzyme powder, costs FIM 561 per period.

\section{Discussion}

The aim of the present study was to determine whether or not the clinical status of dogs with PDA could be improved by feeding them with a special diet designed for dogs with intestinal disorders, rather than feeding ordinary dog food or food prepared by the dog owners. In Finland, it is common to feed the PDA dogs with supplementary pancreas enzymes without much changing the feeding regime. The general opinion is that dog owners usually know what kind of diet is suitable for their dogs.

The study showed clearly that the special diet could significantly reduce some clinical signs of PDA. However, there were considerable differences in the results for the 14 dogs participating in the study. In 6 dogs, the diet did not make much difference.

On the special diet, flatulence,borborygmi, volume of feaces, and defecation frequency were reduced significantly. Positive correlations between signs were surprisingly low. One would have expected, for example, flatulence and borborygmi to be closely correlated, because both signs are supposed to be related to the bacterial growth in the gastrointestinal tract.

The disadvantage of studies of this kind, based on assessment of clinical signs, is that evaluation of at least some signs is fairly subjective. We tried to avoid erroneous evaluations through use of paired comparisons, to eliminate differences between the assessors. Effects of single erroneous evaluations were evened out by calculation of mean scores over a relatively long period.

In the addition of pancreatic enzymes to the food in the present study, half of the dogs received the enzymes in powdered form, half received it in the form of raw pancreas. Differences in clinical signs between these two groups were not statistically significant during either feeding period. In other words, both forms of enzyme supplementation can be considered to be equally effective. In an earlier study (Westermarck 1987), it was noted that the addition of raw pancreas into the food of dogs with PDA resulted in considerably higher enzyme concentrations in the proximal jejunum than those achieved using Viokase $\mathrm{V}$ powder. The present study centered on discovery of any differences in the severity of PDA signs in relation to diets, so that the effects of enzyme supplementation might have gone unnoticed.

Since PDA occurs primarily in large dogs, feeding costs are of great importance. The costs of the special diet were almost double compared to the ordinary diets. From the econc:nic point of view it is probably best to start the treatment of PDA-dogs by adding pancreatic enzymes into their food and giving a course of antibiotics while keeping the diet unchanged. If the dog's status does not improve sufficiently and PDA signs continue, the special diet should be started. Treatment costs can also be reduced consid rably by using pancreas instead of commercial pancreatic enzyme preparations.

\section{References}

Batt RM, McLean L: Comparison of the biochemical changes in the jejunal mucosa of dogs with aerobic and anaerobic bacterial overgrowth. Gastroenterology 1987, 93, 986-993.

Beverly DW, Kelleher J, Macdonald A, Littlewood JM, Robinson T, Walters P: Comparison of four pancreatic extracts in cystic fibrosis. Arch. Dis. Child. 1987, 62, 564-568.

Lewis LD, Morris ML, Hand MS: Small Animal Clinical Nutrition III. 3. ed. Mark Morris 
Associates, Topeka, Kansas 1987 , p. $7-43$ 7-47.

Meyer $H$ : Diätik von Hunden mit exokriner Pankreasinsuffizienz. (Feeding dogs with pancreatic insufficiency). Wien. Tierärztl. Mschr. 1985, 72, 91-95.

Pidgeon $G$ : Effect of diet on pancreatic insufficiency in dogs. J. Amer. vet. med. Assoc. 1982, 181, 232-235.

Pidgeon $G$ : Exocrine pancreatic disease in the dog and cat. Part 2: Exocrine pancreatic insufficiency. Canine Pract. 1987, 14, 31-35.

Räihä $M$, Westermarck $E$ : The signs of pancreatic degenerative atrophy in dogs and the role of external factors in the etiology of the disease. Acta vet. scand. 1989, 30, 447-452.

Strombeck DR: Small Animal Gastroenterology. Stonegate Publishing, Davis, CA, 1979, p. 219-221.

Westermarck $E$ : Treatment of pancreatic degenerative atrophy with raw pancreas homogenate and various enzyme preparations. J. Vet. Med. A $1987,34,728-733$.

Westermarck E, Sandholm M: Faecal hydrolase activity as determined by radial enzyme diffusion: a new method for detecting pancreatic dysfunction in the dog. Res. Vet. Sci. 1980, 28 , 341-346.

Williams DA, Batt RM, McLean L: Bacterial overgrowth in the duodenum of dogs with exocrine pancreatic insufficiency. J. Amer. vet. med. Assoc. 1987, 191, 201-206.

\begin{abstract}
Sammanfattning
Utfodringens betydelse vid bahandlingen

av hundar med degenerativ atrofi

i bukspotskörteln.

I utfodringsförsöket användes 14 hundar med degenerativ atrofi $\mathrm{i}$ bukspottskörteln (PDA). Försöket omfattade 2 perioder av 4 veckor vardera. Under den första perioden fick hundarna vanligt hundfoder, under den andra perioden fick hundarna endast en specialdiet $i$ form av ett kommersiellt, lättsmält foder innehållande en moderat fettmängd och lite fiber. Genom hela försöket tillsattes lika mycket pancreasenzymer i fodret. Ett frågeformulär, täckande 9 typiska symptom för PDA, utdelades åt hundägarna. Dessa ombads dagligen uppskatta svårighetsgraden av symptomen under de båda perioderna, med hjälp av en skala som bifogades frågeformuläret.

Svårighetsgraden av typiska symptom för PDA minskade signifikant $(p<0.05)$ med specialdieten. Av de kliniska symptomen minskade väderavgång, borborygmi, avföringsvolym och -frekvens signifikant $(p<0.05)$ med specialdieten. Inga signifikanta skillnader $\mathrm{i}$ aptit, vätskeintag, färg och konsistens på avföringen och förekomst av koprofagi kunde påvisas mellan de båda utfodringsperioderna.

Specialdieten var i medeltal $90 \%$ dyrare än det vanliga hundfodret.
\end{abstract}

(Received May 15, 1989; accepted October 11, 1989).

Reprints may be requested from: Elias Westermarck, College of Veterinary Medicine, P. O. Box 6, SF-00581 Helsinki, Finland. 